\title{
CIRCULATORY AND VENTILATORY EFFECTS OF HYPERVOLAEMIA IN ARTIFICIALLY VENTILATED PIGLETS
}

\author{
STEN Lindahl
}

ABSTRACT

\begin{abstract}
The influence of hypervolaemia upon circulation and pulmonary ventilation was studied in six piglets (body weights $8.5-10.5 \mathrm{~kg}$ ). A new functional principle for artificial ventilation was used. The alveolar ventilation was unchanged at normovolaemia and hypervolaemia. Arterial blood gases were sampled and end-tidal carbon dioxide concentrations were measured continuously. Central circulation was followed by pressure recordings and an electromagnetic flow meter for cardiac output measurements.

Mean values \pm SEM of end-inspiratory tracheal pressures increased from $0.98 \pm 0.06 \mathrm{kPa}$ at normovolaemia to $1.57 \pm 0.06 \mathrm{kPa}$ at hypervolaemia $(\mathrm{p}<0.02)$. In all animals total compliance decreased $(\mathrm{p}<0.02)$. Simultaneously the insufflation time for the tidal volume decreased by 13 per cent $(p<0.05)$. Arterial oxygen tensions decreased from $8.5 \pm 0.48 \mathrm{kPa}$ to $7.0 \pm 0.77 \mathrm{kPa}(\mathrm{p}<0.05)$.

During hypervolaemia aortic pressures increased from $13.1 \pm 1.3 \mathrm{kPa}$ to $14.9 \pm 0.8 \mathrm{kPa}(\mathrm{p}<$ $0.05)$, pulmonary artery pressures from $2.8 \pm 0.33 \mathrm{kPa}$ to $5.0 \pm 0.53 \mathrm{kPa}(\mathrm{p}<0.02)$ and cardiac output from $1.07 \pm 0.171 \cdot \mathrm{min}^{-1}$ to $1.5 \pm 0.191 \cdot \mathrm{min}^{-1}(\mathrm{p}<0.02)$. The stroke work for the right heart increased by 74 per cent $(p<0.02)$ and for the left heart by 62 per cent $(p<0.02)$. Pulmonary vascular resistance was unchanged, while systemic vascular resistance was significantly decreased $(\mathrm{p}<0.05)$.

The positive effect upon systemic circulation gained by the use of excessive fiuid therapy resulted in an overcirculation within the lungs which reduced pulmonary ventilation. This reduction could most probably be related to a closure of terminal airways secondary to lung hyperperfusion, increasing the pulmonary shunt.
\end{abstract}

Key Words: Blood, Hypervolaemia, Circulation, Ventilation

DURING MAJOR SURGERY and for treatment of the critically ill patient it is of great importance to consider the interaction of fluid balance, lung perfusion, cardiac work and pulmonary ventilation. Due to cardiac failure and longstanding pulmonary congestion compliance of the lungs is known to be reduced. ${ }^{1,2}$ However, the effects of various degrees of acute fluid overload upon pulmonary ventilation is debated. ${ }^{3-5}$ This has become a question of great current clinical interest, as a positive fluid balance is often used to compensate for a potent alpha receptor blockade and to allow the use of high levels of positive end-expiratory pressures. ${ }^{6.7}$

The aim of this study was to follow the circulatory and ventilatory effects of a hypertransfusion at an unchanged alveolar ventilation in healthy anaesthetized piglets ventilated artificially with a new functional principle for artificial ventilation. ${ }^{8}$

Sten Lindahl, M.D., Ph.D., Department of Anaesthesia, University Hospital, S-221 85, Lund, Sweden.

\section{MATERIAL AND METHOD}

Six piglets of the Swedish native breed with blood volumes of about $80 \mathrm{ml} \cdot \mathrm{kg}^{-1}{ }^{9}$ and with body weights between 8.5 and $10.5 \mathrm{~kg}$ were used. Pulmonary ventilation and central circulation was measured at normovolaemia and after infusion of $500 \mathrm{ml}$ of Haemaccel ${ }^{*}$ (Polygelinum NFN). The Haemaccel solution consists of a polymerisation of peptides obtained from gelatin, has a $\mathrm{pH}$ of 7.2-7.3 and is isooncotic.

All parameters such as pressure from the ventilator pressure chamber $\left(P_{\text {vent }}, \mathrm{kPa}\right)$, tracheal end-inspiratory pressure $\left(\mathrm{P}_{\mathrm{e} i}, \mathrm{kPa}\right)$, pleural pressure $\left(\mathrm{P}_{\mathrm{p})}, \mathrm{kPa}\right)$, end-tidal carbon dioxide $\left(\mathrm{PET}_{(\mathrm{C})_{2}}\right.$, $\mathrm{kPa})$, right atrial pressure $\left(\mathrm{P}_{\mathrm{ra}}, \mathrm{kPa}\right)$, left atrial pressure $\left(\mathrm{P}_{\mathrm{la}}, \mathrm{kPa}\right)$, pulmonary artery pressure $\left(P_{\mathrm{AP}}, \mathrm{kPa}\right)$, aortic pressure $\left(\mathrm{P}_{\mathrm{Ao}}, \mathrm{kPa}\right)$ and cardiac output $\left(\dot{Q}, 1 \cdot \mathrm{min}^{-1}\right.$, were registered on two synchronized recorders (Figure 1.)

*Manufactured by Behringwerke AG, Postfach 1130 , D-3550 Marburg/Lahn, Germany 


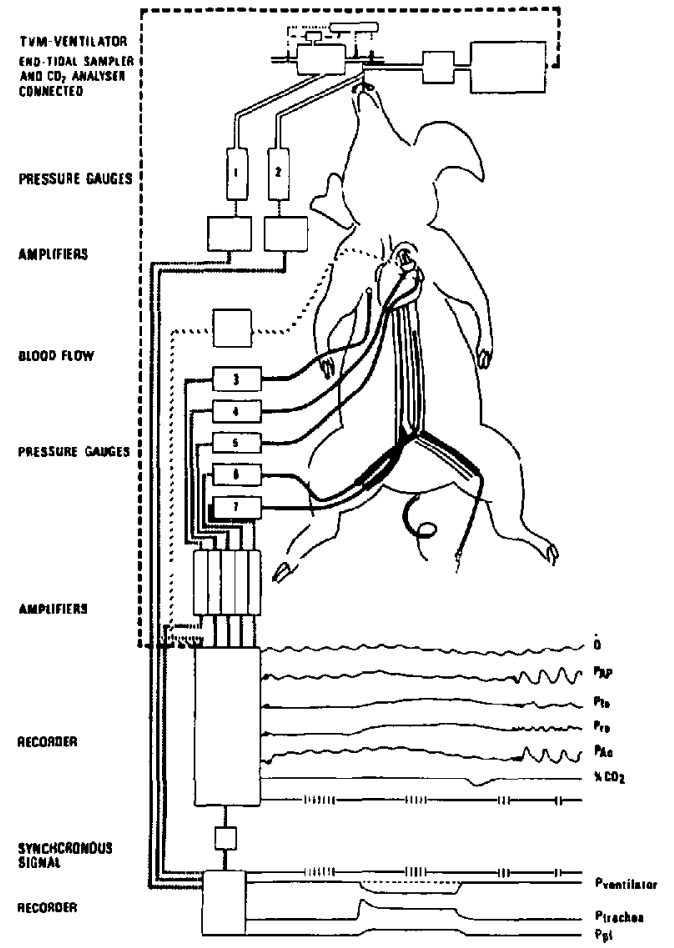

FIGURE 1 The experimental set up and registrations.

\section{Procedure}

The animals were fasted for at least four hours before examination. Dridol (Droperidolum INN) 1-2 $\mathrm{mg} \cdot \mathrm{kg}^{-1}$ and ketamine (Ketaminum hydrochloride NFN) $30-50 \mathrm{mg} \cdot \mathrm{kg}^{-1}$ were injected intramuscularly. The animals were placed on an electrically heated operating table and intubated orotracheally with cuffed plastic tracheal tubes. Alloferin (Alcuronum NFN) 1-2 mg was injected intravenously when needed for muscle relaxation. Air was used as breathing gas. The body temperature was kept within $36.5^{\circ}$ and $37.5^{\circ} \mathrm{C}$.

The femoral artery was dissected free and catheterized for sampling and aortic pressure recordings. A catheter was placed in a femoral vein to allow infusions of 5.5 per cent glucose and injections of muscle relaxants. After sternotomy the pericardial sac was opened. The right and left auricles were catheterized for atrial pressure recordings. A catheter was inserted through the infundibular wall of the ventricle into the main stem of the pulmonary artery. A balloon catheter was placed in the pleural space. The pericardial sac was left open and after careful haemostasis the thoracic cage was closed. The measurements then followed at normovolaemia and after hyper- volaemia. Measurements were carried out after 10-15 minutes of unchanged pulmonary ventilation.

\section{Ventilation}

All animals were ventilated at a ventilatory frequency of 30 with an $I: E$ ratio of $1: 1$. No positive end-expiratory pressure was used. Pulmonary ventilation was set at normoventilation, i.e. $\mathrm{PET}_{\mathrm{CO}_{2}} 4.5-5.5 \mathrm{kPa}$, by reference to an endtidal sampler and an infra-red carbon dioxide analyzer (Godhart, Holland). Frequent momentary analyses of the end-tidal carbon dioxide fractions made it possible to avoid greater fluctuations in the $\mathrm{PCO}_{2}$ during each examination. The infra-red carbon dioxide analyzer was calibrated regularly during the examinations. Three test gases with known carbon dioxide concentrations within the range $2.5-6$ per cent were used. Arterial blood gases were analysed with conventional electrodes (Radiometer, Denmark) and correlated to body temperature.

\section{The ventilator}

A Tidal Volume Monitoring ventilator (TVMventilator*) was used in all animals. (Figure 1) The ventilator consists of a rigid wall pressure chamber (PC), valves and electronic module (EM). During expiration a certain amount of gas enters PC through the filling valve until a certain pressure is reached. The closure of the valve is directed electronically. After a set period, the expiratory valve is closed and the inspiratory valve opens.

Pressure equilibration, i.e. insufflation, occurs within the system - PC, tubing, airways and lungs. The pressure drop $\left(\mathrm{P}_{\text {diff }}\right)$ within $\mathrm{PC}$ during the equilibration procedure is proportional to the volume of gas $\left(\mathrm{VT}_{\text {vent }}, \mathrm{ml}\right)$ that leaves $\mathrm{PC}$ and can be expressed by the formula:

$\mathrm{VT}_{\text {vent }}=\mathrm{P}_{\text {diff }} \times$ constant (2-pressure method according to Okmian.) $)^{10}$

The value of the constant depends upon the volume of $\mathrm{PC}$. In this investigation a volume pressurc relationship $\left(\mathrm{C}_{\text {vent }} \mathrm{ml} \cdot \mathrm{kPa}^{-1}\right)$ of $40 \mathrm{ml} \cdot \mathrm{kPa}^{-1}$ was used. With this ventilator the tidal volume is set breath by breath and read on a dial. The tidal volume setting is independent of the ventilatory frequency setting. Accordingly gas transport and mechanics of ventilation are separate setting procedures.

*Manufactured by Micatrone Regulator Ltd., Stock. holm, Sweden. 


\section{Measurements and calibrations}

An electromagnetic flow meter (Nycotron 372) connected to the recorder (EM 81) was used. Its probe encircled the main stem of the pulmonary artery. The diameter of the probe was chosen so that it was some what smaller than the diameter of the vessel, without causing a pressure gradient.

Electrodynamic pressure gauges (SiemensElema EMT 34), amplifiers, and ink-jet recorders (EM 41 and 81 ) were used. The tracheal pressures were measured from the tracheal tube connection. Instruments for tracheal and pleural pressure measurements were calibrated against a $30 \mathrm{~cm}$ high column of water and instruments for circulatory pressures were calibrated against a water column corresponding to $100 \mathrm{~mm} \mathrm{Hg}$.

\section{Calculations and statistics}

Mechanics of ventilation was estimated by means of total compliance $\left(\mathrm{C}_{\mathrm{TOT}} \mathrm{ml} \cdot \mathrm{kPa}^{-1}\right)$, lung compliance $\left(\mathrm{C}_{\mathrm{L}} \mathrm{ml} \cdot \mathrm{kPa}^{-1}\right)$ and compliance of the thoracic wall $\left(\mathrm{C}_{\mathrm{THX}} \mathrm{ml} \cdot \mathrm{kPa}^{-1}\right)$. The following formulae were used for calculations:

$$
\begin{aligned}
\mathrm{C}_{\text {TOT }} & =\frac{\mathrm{V}_{\mathrm{T}_{\text {vent }}}}{\mathrm{P}_{\mathrm{ei}}} \\
\mathrm{C}_{\mathrm{L}} & =\frac{\mathrm{VT}_{\mathrm{vent}}}{\mathrm{P}_{\mathrm{ei}}-\mathrm{P}_{\mathrm{pl}}} \\
\frac{\mathrm{I}}{\mathrm{C}_{\mathrm{TOT}}} & =\frac{\mathrm{I}}{\mathrm{C}_{\mathrm{L}}}+\frac{\mathrm{I}}{\mathrm{C}_{\mathrm{THX}}} ;
\end{aligned}
$$

For the calculations of pulmonary vascular resistance (PVR, units), systemic vascular resistance (SVR, units), stroke work for the right ventrical (SWR, Nm) and for the left ventrical ( $\mathrm{SWL}, \mathrm{Nm}$ ) the following equations were used:

$$
\begin{aligned}
& P V R=\frac{P_{\mathrm{AP}}-P_{\mathrm{la}}}{Q} ; \quad S V R=\frac{P_{\mathrm{Ao}}-P_{\mathrm{ra}}}{Q} ; \\
& S W R=S V\left(P_{A P}-P_{r a}\right) ; S W L=S V\left(P_{A 0}-P_{t a}\right) ;
\end{aligned}
$$

where $\mathrm{SV}$ is the stroke volume in $\mathrm{ml}$.

Current statistical methods for mean values, standard deviation and standard error of the mean (SEM) were used. Results were evaluated by paired significance tests according to Student's t-test.

\section{RESUlts}

A prerequisite for the comparison of circulation and ventilation at normovalaemia and after hypertransfusion was an unchanged alveolar ventilation. The mean value $\pm S E M$ for arterial carbon dioxide tensions at normovolaemia was $4.5 \pm 0.21 \mathrm{kPa}$. After infusion of $500 \mathrm{ml}$ Haemac- cel the corresponding arterial carbon dioxide tension was $4.2 \pm 0.32 \mathrm{kPa}$. [ $\left.\mathrm{H}^{+}\right] \mathrm{a}$ was $33.11 \pm$ $3.54 \mathrm{nmol} / 1 \mathrm{pH} 7.48 \pm 0.04)$ before and $39.81 \pm$ $4.59(\mathrm{pH} 7.40 \pm 0.05)$ after the infusion. Arterial oxygen tensions decreased from $8.5 \pm 0.48 \mathrm{kPa}$ at normovolaemia to $7.0 \pm 0.77 \mathrm{kPa}$ after hypervolaemia $(p<0.05)$.

Hypertransfusion increased the mean value for $\mathrm{P}_{\mathrm{A} 0}$ from $13.1 \pm 1.3$ to $14.9 \pm 0.8 \mathrm{kPa}(\mathrm{p}<0.05)$ and the $\mathrm{P}_{\mathrm{AP}}$ from $2.8 \pm 0.33$ to $5.0 \pm 0.53 \mathrm{kPa}(\mathrm{p}<$ 0.02 ) (Figure 2). The mean value for the heart rate decreased from $163 \pm 2.1$ to $150 \pm 5.8$ beats $\cdot \mathrm{min}^{-1}$ $(p<0.05)$. Mean values for $P_{1 a}$ increased from 1.4 \pm 0.4 to $2.4 \pm 0.6 \mathrm{kPa}$ and for $\mathrm{P}_{\mathrm{ra}}$ from $0.1 \pm 0.1$ to $1.8 \pm 0.5 \mathrm{kPa}$.

SWR was increased by 74 per cent $(p<0.02)$ and SWL by 62 per cent $(p<0.02)$ after hypervolaemia (Figure 3). This resulted in an increased $\dot{Q}$ from $1.07 \pm 0.17$ to $1.5 \pm 0.191 \cdot \mathrm{min}^{-1}(\mathrm{p}<$ 0.02 , Figure 3). SVR decreased from $13.9 \pm 2.42$ units to $9.6 \pm 1.83$ units i.e. about 30 per cent $(p<$ 0.05 ) while PVR showed an increase from $1.32 \pm$ 0.30 units to $1.93 \pm 0.36$ units (Figure 4), which was not significant.

$P_{\text {vent }}$ increased from $3.38 \pm 0.17 \mathrm{kPa}$ to $3.92 \pm$ $0.11 \mathrm{kPa}(\mathrm{p}<0.05)$ at hypervolaemia. $\mathrm{P}_{\mathrm{e} i}$ in-

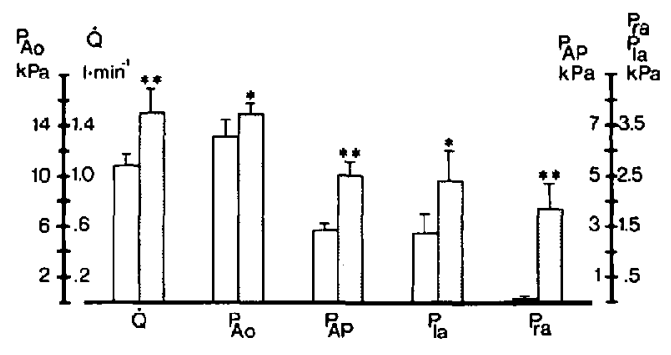

FIGURE 2 Some circulatory data at normovolaemia (white staples) and hypervolaemia (filled staples). Mean values $\pm \operatorname{SEM}(*=p<0.05, * *=p<0.02)$.

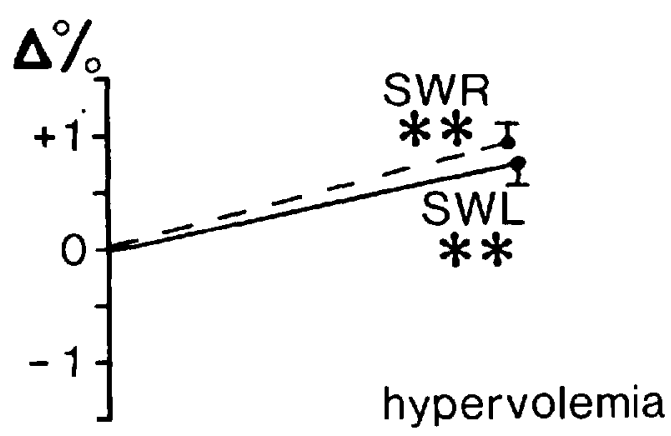

FIGURE 3 Mean values \pm SEM for the changes in SWR and SWL at hypervolaemia in per cent of the values of normovalaemia $(* *=p<0.02)$. 


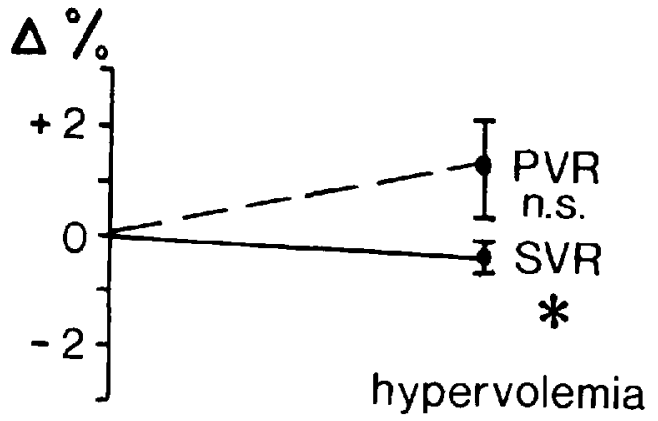

FIgURE 4 Mean values \pm SEM for the changes of SVR and PVR at hypervolaemia in per cent of the values at normovolaemia $\left(^{*}=p<0.05\right.$, n.s. $=$ no significance).

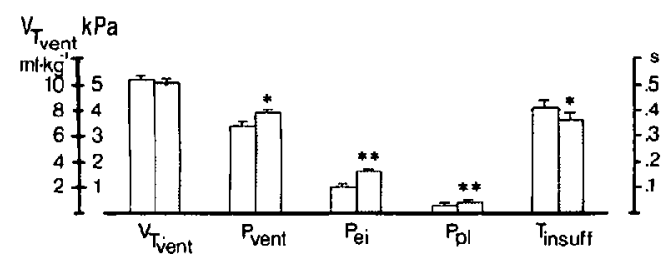

FIgURE 5 Some ventilatory data at normovolaemia (white staples) and hypervolaemia (filled staples). Mean values $\pm \operatorname{SEM}\left({ }^{*}=\mathrm{p}<0.05,{ }^{*}=\mathrm{p}<0.02, \mathrm{~T}_{\text {insuff }}=\right.$ insufflation time in s).

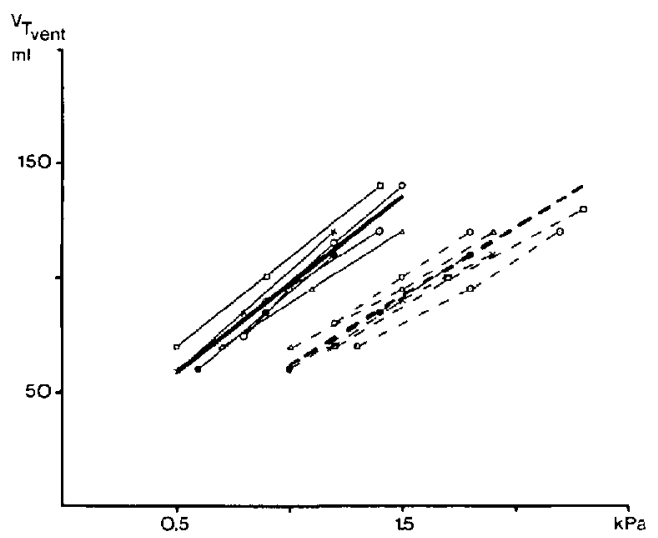

FIGURE 6 Volume-pressure curves at normovolaemia (continuous lines) and at hypervolaemia (dotted lines). Thick lines are mean values.

creased by about 60 per cent from $0.98 \pm 0.06 \mathrm{kPa}$ to $1.57 \pm 0.06 \mathrm{kPa}(\mathrm{p}<0.02)$. $\mathrm{P}_{\mathrm{pl}}$ also increased significantly $(p<0.02)$ while the insufflation time was reduced by 13 per cent $(p<0.05)$ after infusion of $500 \mathrm{ml}$ Haemaccel. (Figure 5).

In all animals the volume-pressure relationship was reduced at hypervolaemia (Figure 6). $\mathrm{C}_{\text {TOT }}$, $C_{L}$ and $C_{T H X}$ were all significantly reduced $(p<$ 0.02 , Figure 7).

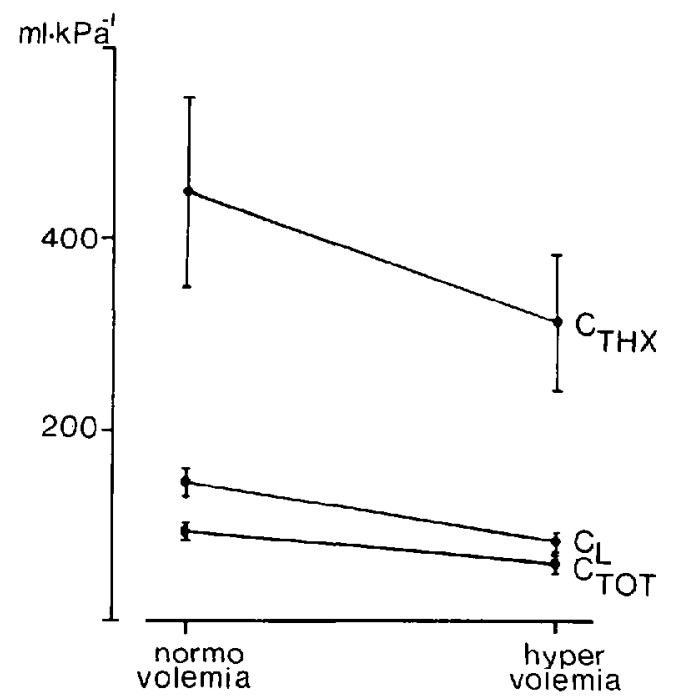

Figure 7 Mean values \pm SEM for $C_{\text {ToT }}, C_{L}$ and $\mathrm{C}_{\mathrm{THX}}$ at normovolaemia and at hypervolaemia.

\section{Discussion}

The piglet was chosen as the experimental animal because of its close physiological relationship to man and the long experience of anaesthetising and breeding the animal at our research laboratory. ${ }^{8,9,11,12}$ It is obvious that quantitative experimental data cannot be directly conclusive for human conditions but qualitative changes during comparative experimental conditions are relevant.

During artificial ventilation changes in mechanics of breathing are known to occur at surgical manipulations and after an increased pulmonary blood volume. ${ }^{13-15}$ These changes must be noticed early for adjustment of tidal volumes. To study the influences upon mechanics of ventilation during hypervolaemia at an unchanged ventilation it was convenient to use a ventilator where accurate tidal volumes could be set, read and adjusted breath by breath. ${ }^{8.14}$ By the use of an end-tidal sampler connected to an infra-red carbon dioxide analyzer it was possible to achieve an unaltered alveolar ventilation, indicated by an unchanged arterial carbon dioxide tension, despite significant reductions of compliance at hypervolaemia.

The arterial oxygen tension was reduced after hypertransfusion caused by a fluid load of about $50 \mathrm{ml} \cdot \mathrm{kg}^{-1}$, i.e. two thirds of the estimated total blood volume of the piglets. The solution used for induction of hypervolaemia was isooncotic with blood, which increased the plasma volume but kept the plasma oncotic pressure unchanged. An 
unaltered oncotic pressure reduces the influence of this factor upon total lung water. ${ }^{16}$ Zetterström, Jakobson and Janerås ${ }^{17}$ showed that a decrease of plasma oncotic pressure by 50 per cent leads to increased lung water content but does not necessarily impair the gas exchange. Rosberg ${ }^{18}$ also found increased oxygen tension after normovolaemic haemodilution. If hypooncotic crystalloid solutions or hyperoncotic solutions like dextran had been used, interpretation of the data would have been more difficult due to the combined interaction upon lung function both from altered plasma oncotic pressure and from a pulmonary overcirculation. By the use of an isooncotic agent, errors due to the fluid alone were considered to be small, which made the study of the initial effects of an increased plasma volume as simple and straight-forward as possible. Therefore, it can be stated that a reduced diffusion capacity of the lungs because of an extravasation of fluid did not seem to be the only and most logical explanation for the decreased arterial oxygen tension found.

After uncomplicated myocardial infarction Hales and Kazemi ${ }^{19}$ found evidence for a premature closure of small airways suggesting transient left ventricular failure and transudation of fluid into the interstitial space of the lung. This agrees with the experimental studies of Demling $^{20}$ who found a correlation between the mean pulmonary capillary pressure and the lung water content in sheep. It is true that the stroke work increased for the left as well as for the right heart, but no sign of cardiac decompensation, evaluated from the moderately increased atrial pressures, was found in these healthy piglets. Pulmonary congestion due to left heart failure also seems to be an unlikely explanation for the decreased arterial oxygen tension.

During spontaneous ventilation in seated men it has been shown that airway closure is gravity dependent i.e. most pronounced in well perfused lung regions. ${ }^{21}$ Previous studies have also shown that changes in the intrathoracic blood volume did influence the physical properties of the lungs. ${ }^{3.22}$ From the pulmonary anatomy it is well known that extra-alveolar lung vessels accompany small airways within a limiting membrane of connective tissue. ${ }^{23}$ In other words prerequisite conditions exist for an interaction between pulmonary artery pressure and small airway function. Davidson, Polliack and Eyal ${ }^{24}$ could relate the muscular closure of terminal airways to the pulmonary artery pressure, a phenomenon not prevented by cervical vagotomy. These pulmonary changes secondary to the pulmonary artery pressure and regional lung perfusion results in non-aerated but well perfused lung areas, which will increase the shunt and lower the arterial oxygen tension. The pulmonary changes would also result in a reduced total compliance, which was shown clearly in this study. At closed terminal airways the significantly reduced insufflation time found could also be expected, from the knowledge of the gas distribution for the same tidal volume within a smaller lung area. ${ }^{25}$ On the other hand, if extravasation of lung water was the main reason for the decreased $\mathrm{C}_{\mathbf{T}}$ t and arterial oxygen tension the insufflation time would not have been reduced.

Acute respiratory insufficiency is one major problem for the critically ill patient and ventilatory assistance is often required. But the critically ill patient also has decreased organ perfusion due to increased systemic vascular resistance in various forms of shock. In this study the systemic vascular resistance was reduced at large fluid amounts. This positive effect upon systemic circulation is the explanation for the frequent use of excessive fluid therapy during intensive care treatment, fluid therapy which nowadays can be administered in a controlled way guided by continuous measurements of capillary wedge pressures and cardiac output. ${ }^{26}$ It is however debated whether crystalloid or colloid solutions should be used for the critically ill patient. ${ }^{27-29}$ Weil, Henning and Puri ${ }^{30}$ suggest that frequent parallel monitoring of plasma oncotic pressure and pulmonary capillary wedge pressure should guide us to select the proper fluid agent, thereby increasing our possibilities for individualising the fluid treatment in intensive care.

It has long been known that when PEEP is used for treatment of hypoxia in acute respiratory insufficiency syndrome a positive fluid balance is required if negative systemic circulatory effects are to be avoided. ${ }^{31}$ Furthermore, Dueck, Wagner and West ${ }^{32}$ pointed out the importance of intact lung perfusion to eliminate the development of lung regions with increased ventilationperfusion ratios caused by high PEEP levels. To avoid these high ventilation-perfusion ratios Walkinshaw and Shoemaker ${ }^{7}$ found that excessive fluid therapy allowed the use of "preferred" PEEP levels to improve arterial oxygen tension in the critically ill patient.

This may seem to be contradictory, as the influence of pulmonary overcirculation upon terminal airway muscles adds to the already decreased pulmonary function after major surgery and trauma. ${ }^{33.34}$ But the pulmonary effects of a fluid load can be compensated for by modern 
ventilator treatment. To keep terminal airways open a ventilatory pattern allowing redistribution of gas (i.e. decellerated inspiratory flow and end-inspiratory pause ${ }^{25}$ ) should be used as well as positive end-expiratory pressure. ${ }^{7,31}$ After a successful outcome from the intensive care period it also deserves to be mentioned that the fluid balance and a possible pulmonary overcirculation should be considered and treated before weaning from the ventilator can be started.

\section{REFERENCES}

1. Frank, N.R., Lyons, H.A., Siebens, A.A. \& Nealon, T.F. Pulmonary compliance in patients with cardiac disease. Amer. J. Med. 22:516 (1957).

2. Ayres, S.M., Kozam, R.L. \& Lukas, D.S. Mechanics and work of breathing in atrial septal defect. Circulation 22: 718 (1960).

3. Gianelli, S., Ayres, S.M., Buehler, M.E. Armstrong, D.R. \& Stuart, M.E. Effect of pulmonary blood flow upon lung mechanics. J. Clin. Invest. 46: 1625 (1967).

4. Bondurant, S., Mead, J. \& Cook, C.D.. A re-evaluation of effects of acute central congestion on pulmonary compliance in normal subjects. $J$. Appl. Physiol. 15: 875 (1960).

5. Attinger, E.D. Pulmonary mechanics and hemodynamics during changes in ventilation and blood volume. J. Appl. Physiol. 15: 429 (1960).

6. EklöF, B., Neglén, P.\& Thomson, D. Temporary incomplete ischemia of the legs induced by aortic clamping in man: Effects on central hemodynamies and skeletal muscle metabolism by adrenergic block. Submitted for publication in Ann. Surg. (1980)

7. Walkinshaw, M. \& Shoemaker, W.C. Use of volume loading to obtain preferred levels of PEEP. Crit. Care. Med. 8: 81 (1980).

8. LINDAHL, S. \& OKmIAN, L. Experimental studies on artificial ventilation using a tidal volume ventilator. Acta Anaesth. Scand. 23: 359 (1979).

9. Bustad, L.K. Pigs in the laboratory. Scientific Am. 2/4: 94 (1966)

10. OKMIAN, L. Artificial ventilation by respirator for newborn infants during anaesthesia. A method using a new formula and a new nomogram. Acta Anaesth. Scand. 7: 31 (1963).

11. Dyrendahl, S., Swahn, O., Buörck, G. \& HellVING, L. Artificial raising of baby pigs. Acta Agric. Scand. 3: 334 (1953).

12. KORNFÄLT, S.. . Stricture formation in anastomoses and mucosal defects in the esophagus. An experimental study in the piglet. Bull of the Dep. of Surgery No. 3, University of Lund, Sweden (1973).

13. Okmian, L., Wallgren, G. \& WÄhlin, Å. Artificial ventilation by respirator for newborn and small infants during anaesthesia. Mechanics of ventilation. Acta Anaesth. Scand. 10: 181 (1966).

14. Lindahl, S., OKmian, L. \& Thomson, D. Artificial ventilation in children during anaesthesia using a tidal volume ventilator. Acta Anaesth. Scand. 23: 587 (1979).

15. Anscombe, A.R. \& Buxton, R.S. Effect of abdominal operations on total lung capacity and its subdivisions. Brit. Med. J. 2: 84 (1958).
16. Zetterström, H. Plasma oncotic pressure and lung function. Clinical and experimental aspects Thesis. Uppsala, Sweden (1980).

17. ZetTerström, H., Jakobson, S. \& Janer\&̊s, L. Influence of plasma oncotic pressure on lung water accumulation and gas exchange after experimental lung injury in the pig. Acta Anaesth. Scand. Accept. for publication (1980).

18. RosberG, B. Acute normovolemic hemodilution. Clinical and experimental studies on hemodynam. ics and regional lung function. Thesis. Malmö. Sweden (1978).

19. Hales, C.A. \& Kazemı, H. Small-airways function in myocardial infarction. N. Engl. J. Med. 290: 761 (1974).

20. Demling, R.H. Correlation of changes in body weight and pulmonary vascular pressure with lung water accumulation during fluid overload. Crit. Care Med. 7: 153 (1979).

21. Forkert, L., Dhingra, S. \& ANthonisen, N.R Airway closure and closing volume. J. Appl. Physiol, 46: 24 (1979).

22. SYKes, M.K., AdAMS, A.P., Finlay, W.E.I. Wightman, A.E. \& MUNroe, J.P. The cardiorespiratory effects of haemorrhage and overtransfusion in dogs. Brit. J. Anaesth. 42: 573 (1970).

23. Hafferl, A. Lehrbuch der Topographischen Anatomie, Zweite Auflage, 332, Berlin-GöttingenHeidelberg, Springer-Verlag, Germany (1957).

24. Davidson, J.T., Polliack, A. \& Eyal, Z. Static pressure-volume curve of the rabbit lung as modified by the injection of dextran and vagotomy. Brit. J. Anaesth. 42: 585 (1970).

25. LINDAHL, S. Influence of an end-inspiratory pause on pulmonary ventilation, gas distribution and lung perfusion during artificial ventilation. Crit. Care Med. 7: 540 (1979).

26. Forrester, J.S., Ganz, W., Diamond, G., MCHugh, T., Chonette, D.W. \& SWan, H.J.C. Thermodilution cardiac output determination with a single flow-directed catheter. Am. Heart J. 83: 306 (1972).

27. Virgillo, R.W., Smith, D.E. \& Zarins, C.K Balanced electrolyte solutions; experimental and clinical studies. Crit. Care Med. 7: 98 (1979).

28. Lowe, R.J., Moss, G.S., JiLEK, J. \& LeviNe, H. Crystalloid versus colloid in the etiology of pulmonary failure after trauma - a randomized trial in man. Crit. Care. Med. 7: 107 (1979).

29. Shoemaker, W.C. \& Hauser, C.J. Critique of crystalloid versus colloid therapy in shock and shock lung. Crit. Care Med. 7: 117 (1979).

30. Weil, M.H., Henning, R.J. \& PuRI, V.K. Colloid oncotic pressure: clinical significance. Crit. Care Med. 7: 113 (1979).

31. Ashbaugh, D.G. \& Petry, T.L. Post end-expiratory pressure. J. Thorac. Cardiovasc. Surg. 65: 165 (1973).

32. Dueck, R., WaGner, P.D. \& West, J.B. Effects of positive end-expiratory pressure on gas exchange in dogs with normal and edematous lungs. Anaesthesiology 47: 359 (1977).

33. Pontoppidan, H., Laver, M.B. \& Geffin, B. Acute respiratory failure in the surgical patient. Advances. Surg. 4: 163 (1970)

34. Pontoppidan, H. Treatment of respiratory failure in non-thoracic trauma. J. Trauma 8: 938 (1968). 


\section{RÉSUMÉ}

Les réprecussions circulatoires et respiratoires de l'hypervolémie ont été étudiées chez six porcelets de 8.5 à $10.5 \mathrm{~kg}$. La ventilation artificielle des animaux était assurée au moyen d'un appareil fonctionnant selon un nouveau principe assurant une ventilation alvéolaire constante à la fois en normovalémie et en hypervolémie. Les gaz artériels et la $\mathrm{PCO}_{2}$ de fin d'expiration étaient mesurés de façon continue. Des canules appropriées permettaient le monitoring de la circulation centrale et un débit-mètre électromagnétique fournissait les mesures du débit cardiaque.

$\mathrm{La} \mathrm{Pa}_{\mathrm{CO}_{2}}$ diminutait en hypervolémie. Les compliances pulmonaires totales, thoracique et pulmonaire ainsi que le temps d'insufflation du volume courant étaient significativement diminués après surtransfusion des animaux. On notait d'autre part que le débit cardiaque, les pressions aortiques et pulmonaires et le travail d'éjection des ventricules droit et gauche s'élevaient dans ces circonstances. Les résistances vasculaires pulmonaires n'étient pas modifiées, alors que l'on observait une diminution significative des résistances vasculaires périphériques.

Les effets circulatoires positifs d'une hypervolémie se traduisent donc par une augmentation de la circulation pulmonaire avec diminution de la ventilation. Cette diminution est probablement due à la fermeture des bronchioles terminales par augmentation de la perfusion pulmonaire avec augmentation du shunt.

Au cours de la ventilation artificielle chez le patient en condition critique, les répercussions respiratoires d'une hypervolémie peuvent être compensées par l'utilisation d'une pause en fin d'inspiration et d'une PEEP. 